\title{
Changes in Land Cover in Cacheu River Mangroves Natural Park, Guinea-Bissau: The Need for a More Sustainable Management
}

\author{
Eva M. García del Toro ${ }^{1, *}$ and María Isabel Más-López ${ }^{2}$ \\ 1 Departamento de Ingeniería Civil: Hidráulica y Ordenación del Territorio, ETS Ingeniería Civil Universidad \\ Politécnica de Madrid, 28014 Madrid, Spain \\ 2 Departamento de Ingeniería Civil: Construcción Infraestructura y transporte, ETS Ingeniería Civil \\ Universidad Politécnica de Madrid, 28014 Madrid, Spain; mariaisabel.mas@upm.es \\ * Correspondence: evamaria.garcia@upm.es
}

Received: 14 October 2019; Accepted: 6 November 2019; Published: 7 November 2019

\begin{abstract}
The aim of this paper is to study the evolution of vegetation and potential changes in land use in the Cacheu River Mangroves Natural Park in the Republic of Guinea-Bissau. To do this, we will study variations in the Normalized Difference Vegetation Index (NDVI). In order to perform the calculations and subsequent analysis, images of the park from the years 2010 and 2017, corresponding to the same period of the year, so that the phenological stage is the same, were used. To perform a more reliable analysis, the park was divided into five different areas based upon the vegetation type or main use of the land in each of them; i.e.: mangals, palm forest, paddies, savannahs and others. Using a statistical sample, the NDVIs were calculated for each of these areas. The study made it possible to conclude that the changes in land cover observed represent a decrease in mangrove swamps, which are probably being replaced by other land uses, despite the fact that these forests constitute the most important ecological area of all those that make up the park. The park will therefore benefit from a more sustainable management.
\end{abstract}

Keywords: mangals; sustainability; vegetation indices; land use; environmental management

\section{Introduction}

Around the world, one hundred and sixty-three countries and territories with a total forest area of 3.7 billion ha. recently reported that about 2.2 billion ha. are intended to be maintained under permanent forest land use. Of these, close to 1 billion ha. are found in the tropics [1]. The rich biodiversity of these areas and the many roles they play in the functioning of the Earth system at local, regional and global scales, are the reason behind the effort of maintaining these areas for permanent forest use [2]. Of the world's major tropical forest regions, most research and policy attention has focused upon the Amazon Region; whereas, the tropical forests of Central and West Africa, which constitute world's second largest tropical forest region, have been relatively neglected [3].

The Natural Park of the Mangroves of the Cacheu River in Guinea-Bissau is one of the most extensive mangrove areas of West Africa, and its importance for nature conservation was stablished during the 1980s by the Guinean authorities and the World Conservation Union [4,5]. Furthermore, this area was included in the RAMSAR list in 2015 (after Ramsar a city in Iran, wherein the 1971 Ramsar Convention was signed) [6]. The great environmental relevance, in addition to the particular socio-economic conditions of the area, make it especially vulnerable and in need of conservation. For these reasons, the Cacheu River Natural Park was chosen as the area of study. This area was stablished as a Natural Park in 2000 [5]. The park is located in northwest Guinea-Bissau, between $12^{\circ} 10^{\prime}-12^{\circ} 25^{\prime} \mathrm{N}$ and $15^{\circ} 55^{\prime}-16^{\circ} 27^{\prime}$ W. Its location is shown in Figures 1 and 2. 


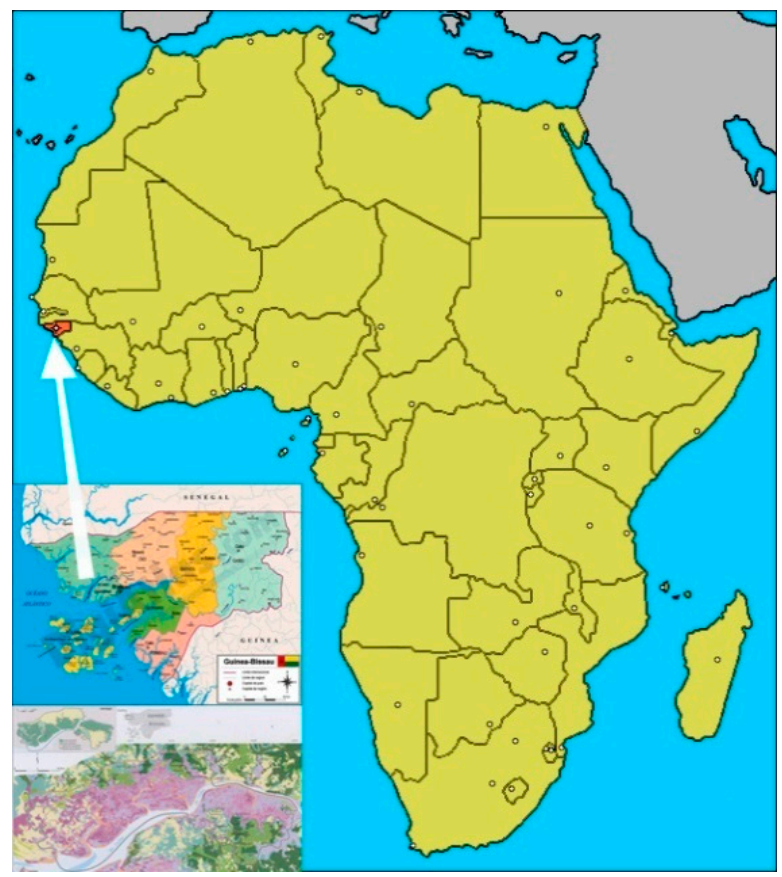

Figure 1. General map of the location of Guinea-Bissau and Cacheu River Mangroves Natural Park. Source: Images taken from the Internet, as well as from various sources and superposed manually by the author.

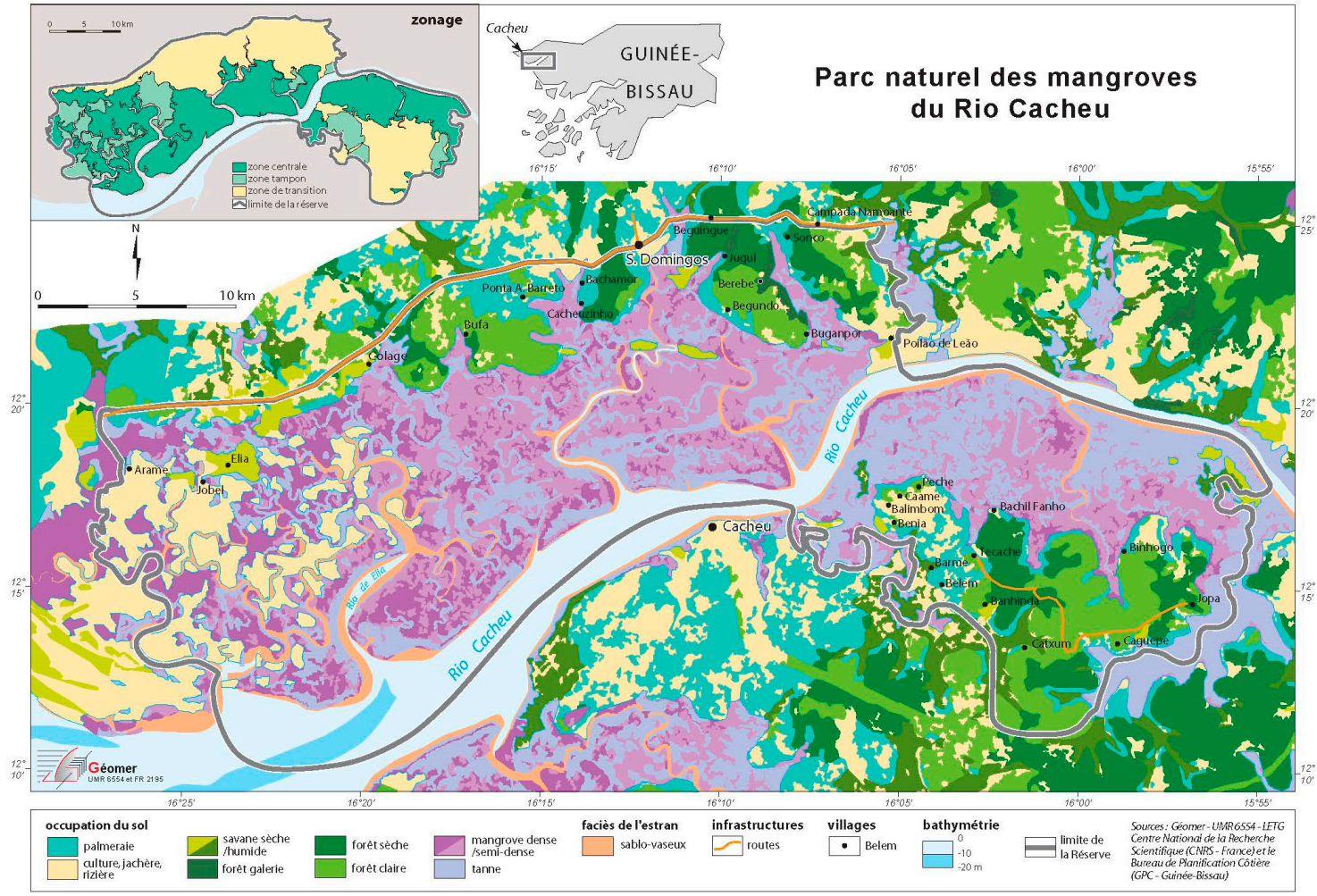

Figure 2. Location map of Cacheu River Mangroves Natural Park. Source: RAMSAR.

The park's total vegetation extends across an area of 88,615 ha., $68 \%$ of which is covered by mangals. Mangroves are a group of trees and shrubs, mostly evergreen, which have convergently theoretically evolved physiological and morphologically to adapt to shallow, intertidal environments [7]. 
These shrubs or small trees grow at the interface between land and sea in tropical and sub-tropical latitudes, where they exist in conditions of high salinity (halophytes) and harsh coastal conditions, such as extreme tides, strong winds and high temperatures [8]. They are also adapted to the low oxygen conditions of waterlogged mud [9]. Mangroves stand out for the important ecological work that they perform [10]:

- They form a protective barrier against tsunamis and tidal waves $[11,12]$ due to the stability created by the complex framework of their roots. In addition, the aerial part, made up of stems and branches that form a tall, dense canopy, is a natural barrier against wind erosion and protection against hurricane-force winds.

- The roots of the tree and shrub species function like a green filter, neutralizing pollutants, such as heavy metals and toxic compounds [13]. They therefore purify the waters of rivers and effluents from surrounding settlements and small industries.

- They form mating and breeding areas, and the habitat for the juvenile stages of many coastal pelagic fish, mollusks, crustaceans, echinoderms and annelids, whose habitats in the adult stages are areas of phanerogams, marshes, coastal lagoons and inland fresh water [14]. Approximately $70 \%$ of the organisms captured at sea carry out part of their life cycle in a mangrove swamp or coastal lagoon [15]. The great variety of species to which the mangals are home make up a complicated trophic network, maintaining a large number of reptile and bird species, some of which are endangered.

- They are important carbon sinks, and produce large amounts of oxygen, which they return to the atmosphere [16]. Furthermore, as they are effective $\mathrm{CO}_{2}$ fixers, and also because of the redox reactions they carry out on nitrous oxide, one of the main greenhouse gases, they are a palliative against climate change [17].

- They regulate the flow of rainwater and reduce the effects of flooding [11].

- The mangroves are a source of obtaining medicinal plants for the populations that inhabit them [18].

All these aspects provide the rationale as to why community-based mangrove management has been advocated by both academia and governing agencies and emphasize [19] the need for sustainably managing the mangrove forests, which are unfortunately disappearing rapidly worldwide [20].

The mangals in this Guinea-Bissau Natural Park include the following species: Rhizophora racemosa, Rhizophora mangle, Rhizophora harrisonii and Avicennia germinans, Laguncularia racemose, Canocarpus erectus and Machaerium lunatum) [21]. Associated with this forest, we also find animal species such as the hippopotamus (Hippopotamus amphibius), Nile crocodile (Crocodylus niloticus) and the manatee (Trichechus spp.). The park also provides shelter for a large number of birds [22].

In addition to mangals, the area of study also contains large areas of palm forest, savannah and paddies, mixed with small population centers, where the cashew crop stands out [4].

- The palm forest area is made up of various species: Pterocarpus erinaceus, Dialium guineense, Khaya senegalensis, Parinari excelsa, Landolphia spp. and Elaesis guineensis [21]. Of these, the last one-Elaesis guineensis-is the most important, as its seeds produce a highly prized vegetable oil widely used in different industrial sectors.

- The savannah area constitutes the smallest association in the park. It is made up of gramineous plants from different genera, most notably Panicum, Hypoltenio and Melinis [23]. There is a scattering of acacias (Acacia arabica, Acacia senegal and Acacia catechu).

The paddy area is the result of Portuguese colonization, as the Portuguese colonists introduced this crop [24]. In recent years, they appear to have expanded considerably due to the increase in population in the area of the natural park $[25,26]$. 
This paper focuses on studying the changes in land cover and the evolution of vegetation in the Cacheu River Mangroves Natural Park between the years 2010 and 2017. The study is aimed at evaluating the sustainability of the natural park, particularly of the mangrove area, based upon the above-mentioned changes over time.

\section{Materials and Methods}

There are different types of remotely-sensed data and several methods to analyze it that can be used to assess changes in land cover [27]. For the present study, vegetation indices were used to quantify the biomass in the Cacheu River Natural Park, its current state, and its evolution over time [28] with the purpose of evaluating its sustainability according to the current exploitation. These vegetation indices are calculated from digital images resulting from the processing of satellite data.

Specifically, the Normalized Difference Vegetation Index (NDVI) was chosen for the present research because it is the index that demonstrates a more homogeneous behavior with respect to different types of plant cover [29]. In addition, previous studies carried out in different areas of Asia corroborate the effectiveness of using the NDVI for the determination of mangrove forests, which are a key vegetation type in the area of study [30-32].

The NDVI is also an excellent indicator of plant health; a high value for this index means vigorous growth, while a low index indicates unhealthy plants [28].

The NDVI is calculated based on the data corresponding to the red and near-infrared channels of the TERRA (Latin for Earth) satellite by means of its Advanced Spaceborne Thermal Emission and Reflection Radiometer (ASTER) sensor [33].

The cartographic data used in the study were based on military maps, which are on the Universal Transverse Mercator coordinate system (UTM) and International ellipsoid. The distance between contour lines is 10 meters. The sheets necessary to produce the mosaic map are those shown in Table 1 below.

Table 1. Map sheets used to create the mosaic of the park.

\begin{tabular}{|c|c|c|c|c|c|}
\hline $\begin{array}{c}\text { VARELA } \\
\text { (February 1954) }\end{array}$ & $\begin{array}{c}\text { SUSANA } \\
\text { (February 1953) }\end{array}$ & $\begin{array}{c}\text { S. Domingos } \\
\text { (February 1953) }\end{array}$ & $\begin{array}{c}\text { SEDENGAL } \\
\text { (February 1953) }\end{array}$ & $\begin{array}{c}\text { BIGENE } \\
\text { (February 1954) }\end{array}$ & $\begin{array}{c}\text { BINTA } \\
\text { (February 1954) }\end{array}$ \\
\hline & $\begin{array}{l}\text { JUFUNCO } \\
\text { (March 1951) }\end{array}$ & $\begin{array}{c}\text { T. PINTO } \\
\text { (February 1954) }\end{array}$ & $\begin{array}{c}\text { PELUNDO } \\
\text { (February 1954) }\end{array}$ & $\begin{array}{c}\text { BULA } \\
\text { (February 1954) }\end{array}$ & $\begin{array}{c}\text { MANSOA } \\
\text { (February 1954) }\end{array}$ \\
\hline & $\begin{array}{l}\text { I.DE JETA } \\
\text { (March 1951) }\end{array}$ & $\begin{array}{c}\text { CAIO } \\
\text { (March 1950) }\end{array}$ & $\begin{array}{l}\text { QUINHAMEL } \\
\text { (February 1948) }\end{array}$ & $\begin{array}{c}\text { BISDSAU } \\
\text { (February 1945) }\end{array}$ & $\begin{array}{c}\text { TITE } \\
\text { (February 1954) }\end{array}$ \\
\hline & & & & $\begin{array}{c}\text { BOLAMA } \\
\text { (May 1948) }\end{array}$ & $\begin{array}{c}\text { S.JOAO } \\
\text { (May 1945) }\end{array}$ \\
\hline
\end{tabular}

The ASTER images corresponding to the park and the period studied were also required. The image search was done using the ASTER-LANDSAT-USGS-Globalvis catalog [33].

The ASTER scenes were chosen based on the following selection criteria:

- Cloud percentage: $0 \%$

- Images covering the entire area of the park

- Search period: January 2008-December 2017

- Time of year: Spring, as this is the period when the vegetation is in its optimum state.

As a result of this search using the criteria described above, a total of 21 scenes were obtained.

The first ASTER scenes of the park that could be obtained were from July 2008, but they were discarded because they covered a very limited area of the park and the cloud percentage was very high. Expanding the search range to 2010 and discarding the two scenes from 2008, it was only possible to select five scenes, of which just three were valid, given that they were from similar dates and also covered the entirety of the Cacheu River Park. 
Therefore, the main determining factor when selecting the year in which to begin the study and the time of year, was the availability of adequate ASTER scenes for the park.

Once the appropriate material, country maps and ASTER images were selected, the NDVIs were calculated. The first step consisted of georeferencing the map sheets, based on the 1/50,000 scale country map sheets shown in Table 1 . These were processed to create the mosaic used as a base to make up the park. The modus operandi is laid out below:

- Preparation of the map sheets;

- Cutting the $1 / 50,000$ sheets;

- Geometric correction of the sheets;

- Creation of the mosaic map from all the $1 / 50,000$ sheets that make up the entire Cacheu River Park.

Once the map sheets of the park had been georeferenced, a vector file was created based on the map downloaded from the RAMSAR site [6]. This was then digitized and georeferenced.

The next step in obtaining the vegetation indices involved the processing of the ASTER images from the TERRA satellite. This consisted of:

- Geometric correction of each of the images;

- Atmospheric correction of the images;

- Cutting each scene.

Having properly processed the ASTER images for the area under study, the ASTER mosaics were created for the years 2010 and 2017, and the NDVI for each ASTER scene was calculated. Next, the statistics for each of the plots were obtained for each of the classes considered.

In order to concentrate the results in the Cacheu River Natural Park, each mosaic was cut along the park vector. Next, the attributes of each resulting image were edited based on the criteria for designating categories and colors shown in Table 2.

Table 2. Designation of Normalized Difference Vegetation Index (NDVI) colors and categories.

\begin{tabular}{ccccc}
\hline Category & NDVI $[-\mathbf{1}, \mathbf{1}]$ & NDVI [0, 255] & Vegetable Cover & Color \\
\hline 0 & $<0$ & $<127$ & Null & \\
\hline 1 & $0-0.2$ & $128-153$ & Low & \\
\hline 2 & $0.2-0.4$ & $154-179$ & Middle-low & \\
\hline 3 & $0.4-0.6$ & $180-205$ & Middle & \\
\hline 4 & $0.6-0.8$ & $206-231$ & Middle-high & \\
\hline 5 & $0.8-1.0$ & $232-255$ & High & \\
\hline
\end{tabular}

\section{Results}

The resulting images, edited with the appropriate NDVI color coding based on the calculations made, are shown below as Figures 3 and 4 .

Comparing the colors on the figures obtained, it is clear that the vegetation has undergone changes during the time of study. To confirm this, statistical calculations were performed on the ASTER scene mosaics with NDVI for the years 2010 and 2017.

The statistical variables analyzed were the maximum and minimum value, mean, median, mode and standard deviation of the vegetation index. 


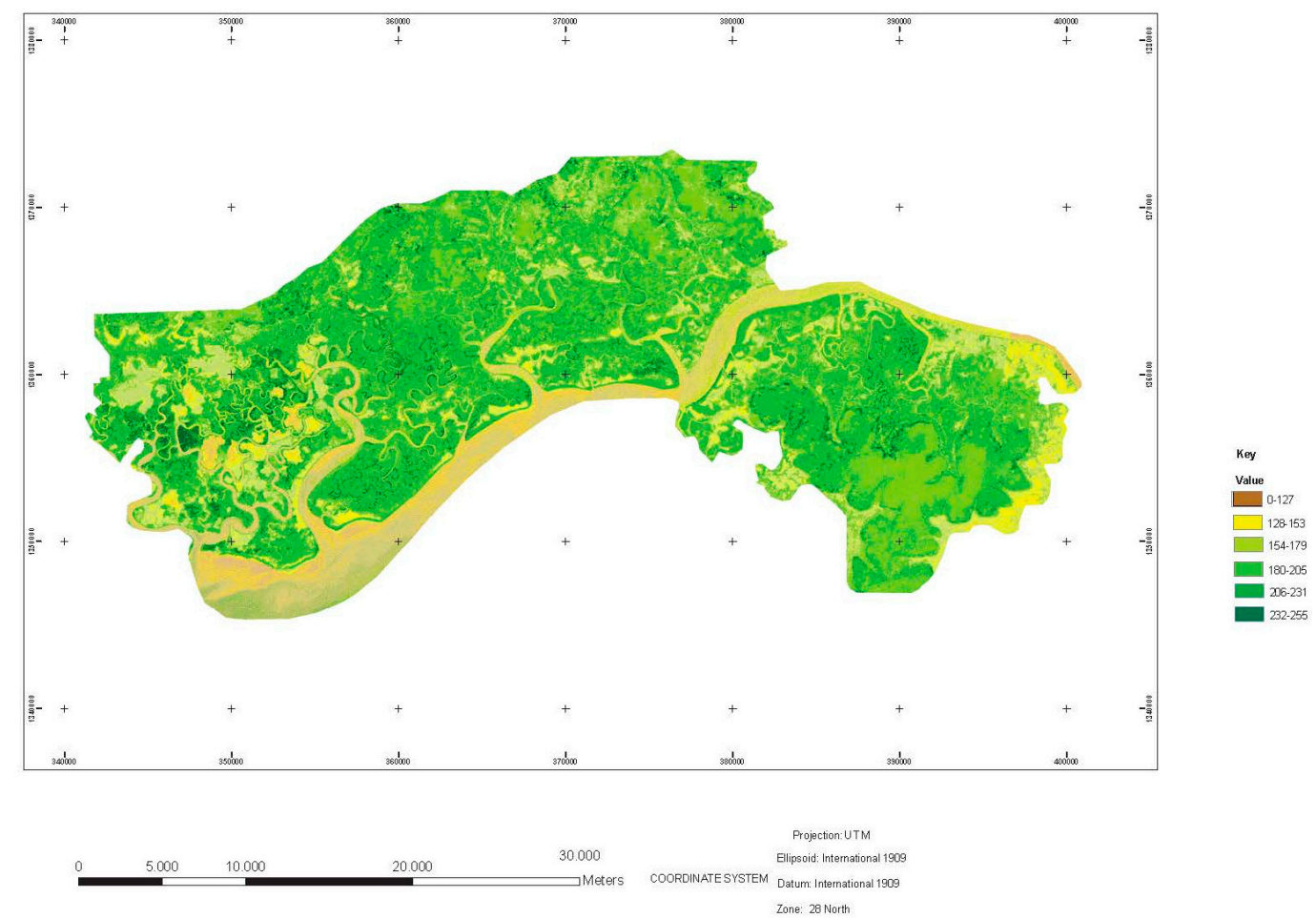

Figure 3. Mosaic with NDVI for the year 2010.

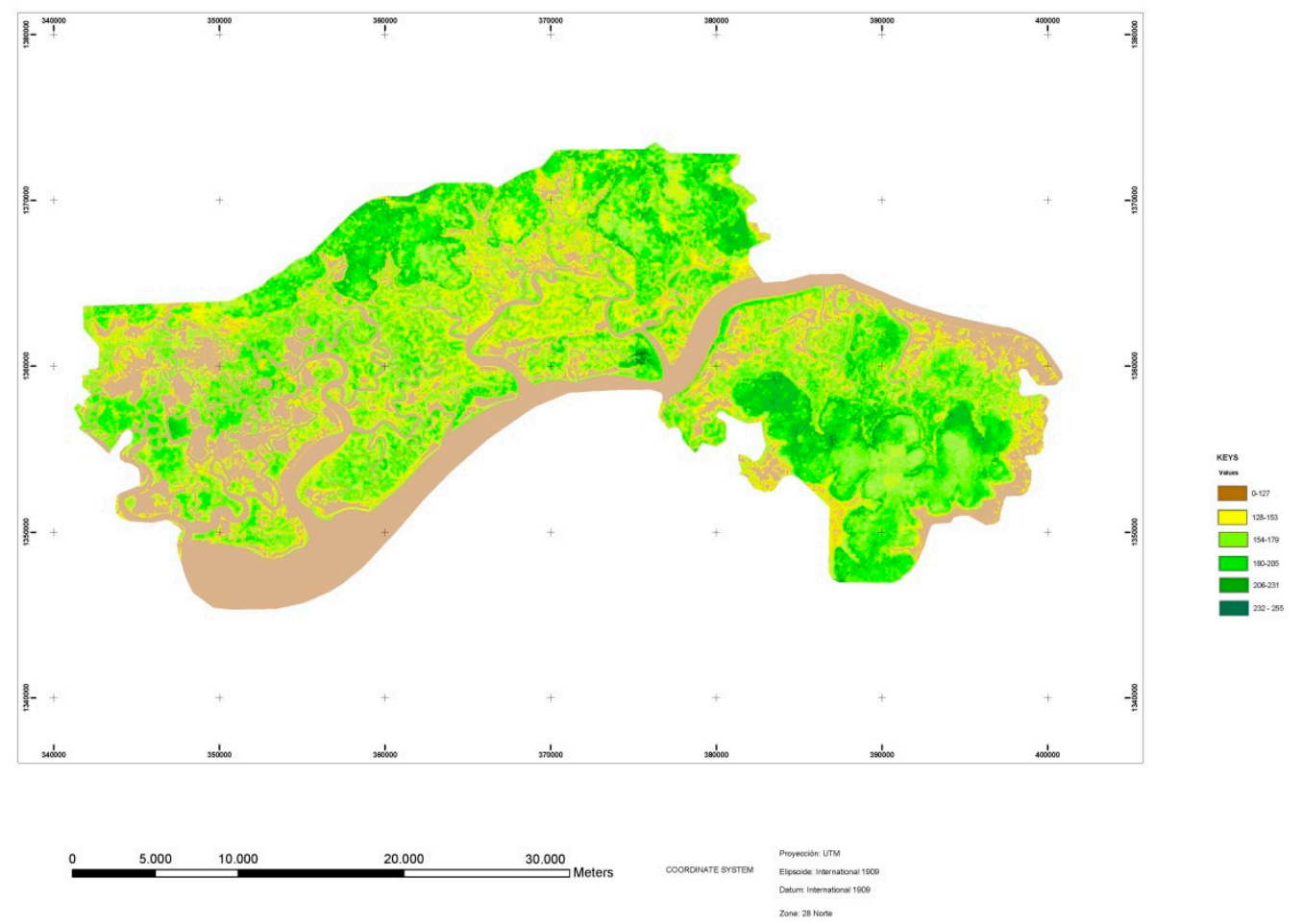

Figure 4. Mosaic with NDVI for the year 2017.

The statistical calculations were first applied to the entire area of the park, as shown in Table 3. This gave us an overview of what happened in the entire park over the course of the period studied.

The overall NDVIs for the park for each year studied confirm what it was already possible to see in the ASTER images: The vegetation has undergone significant changes. The general trend observed 
is a decrease in the vegetation indices through the period studied. This indicates that, generally, the areas covered by vegetation have decreased.

Table 3. NDVI statistical results for the entire park.

\begin{tabular}{ccccc}
\hline YEAR & MEAN & MEDIAN & MODE & STD \\
\hline 2010 & 192.907 & 195 & 171 & 26.764 \\
2017 & 151.470 & 153 & 137 & 30.579 \\
\hline
\end{tabular}

Same calculations were subsequently done for each of the selected areas with the different vegetation types, using stratified statistical sampling. Ten plots of each vegetation type were digitized, except for savannahs, for which only five plots were available. Results per plot and year are presented in the sections below.

\subsection{Mangals}

For all of the plots, a decrease in NDVI was observed in the mangal area between 2010 and 2017. This decrease can be seen in Table 4 and Figure 5.

Table 4. NDVI statistical results for the mangals area.

\begin{tabular}{ccccccccc}
\hline \multicolumn{9}{c}{2010} \\
Plot & Mean & Median & Mode & STD & Mean & Median & Mode & STD \\
\hline 1 & 213.001 & 214 & 213 & 14.261 & 160.000 & 163 & 169 & 24.554 \\
2 & 185.030 & 179 & 172 & 20.959 & 101.995 & 86 & 79 & 40.213 \\
3 & 216.003 & 215 & 213 & 8.781 & 170.542 & 171 & 169 & 16.389 \\
4 & 214.952 & 215 & 210 & 11.597 & 174.829 & 174 & 169 & 21.006 \\
5 & 209.199 & 211 & 210 & 18.708 & 173.635 & 174 & 169 & 31.858 \\
6 & 210.089 & 209 & 210 & 8.495 & 161.230 & 159 & 169 & 17.9 \\
7 & 210.110 & 213 & 213 & 17.173 & 164.841 & 166 & 169 & 26.832 \\
8 & 206.030 & 208 & 204 & 16.27 & 160.913 & 160 & 169 & 23.71 \\
9 & 191.952 & 198 & 204 & 21.663 & 156.634 & 161 & 169 & 27.16 \\
10 & 215.241 & 216 & 213 & 11.968 & 181.988 & 184 & 190 & 19.859 \\
\hline
\end{tabular}

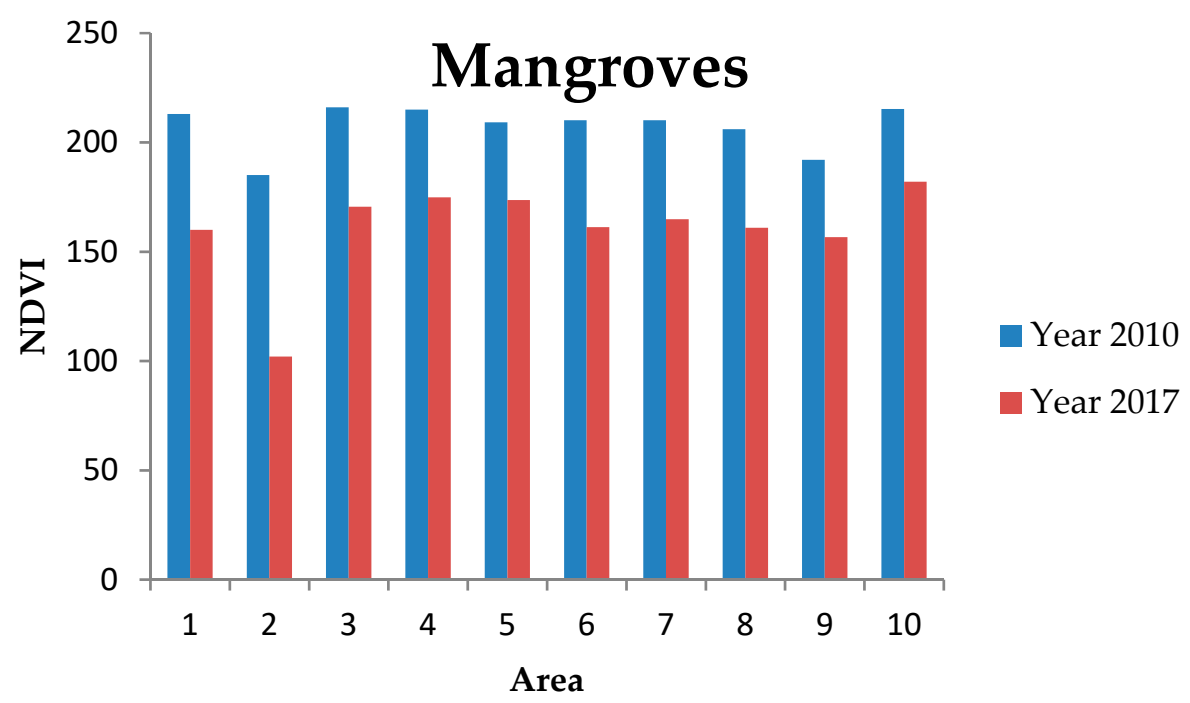

Figure 5. Comparison for mean NDVI between 2010 and 2017 in the mangal area.

\subsection{Paddies}

In Table 5 and Figure 6 can be seen that the NDVI index has increased for the paddy class, which implies that the biomass in this area has increased over the period of time that has been studied. 
Table 5. NDVI statistical results for the paddy area.

\begin{tabular}{ccccccccc}
\hline \multicolumn{9}{c}{2010} \\
Plot & Mean & Median & Mode & STD & Mean & Median & Mode & STD \\
\hline 1 & 169.964 & 165 & 164 & 22.897 & 110.178 & 107 & 108 & 29.742 \\
2 & 201.299 & 214 & 227 & 32.251 & 148.309 & 160 & 171 & 37.633 \\
3 & 198.201 & 210 & 218 & 32.497 & 150.009 & 162 & 169 & 43.61 \\
4 & 167.891 & 162 & 169 & 31.409 & 115.267 & 107 & 127 & 40.56 \\
5 & 184.236 & 177 & 170 & 26.138 & 123.112 & 117 & 108 & 31.1 \\
6 & 206.060 & 216 & 234 & 29.095 & 157.913 & 166 & 185 & 34.077 \\
7 & 186.072 & 175 & 170 & 25.6 & 135.76 & 122 & 118 & 31.083 \\
8 & 210.021 & 219 & 227 & 25.901 & 176.587 & 180 & 169 & 21.836 \\
9 & 202.925 & 218 & 228 & 32.235 & 152.541 & 169 & 171 & 36.013 \\
10 & 194.918 & 218 & 236 & 44.466 & 139.939 & 173 & 185 & 64.097 \\
\hline
\end{tabular}

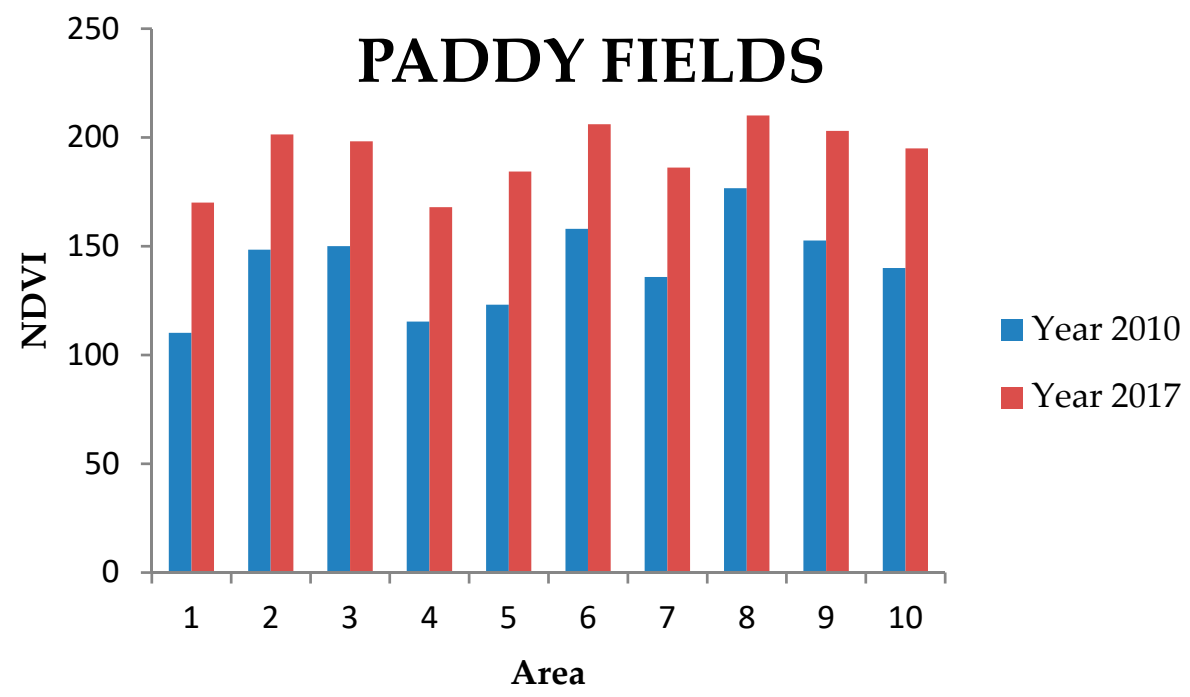

Figure 6. Comparison for mean NDVI between 2010-2017 in the paddy field area.

\subsection{Palm Forest}

Table 6 and Figure 7 show that the vegetation index for the palm forest area has been decreased on all plots during the period studied.

Table 6. NDVI statistical results for the palm forest area.

\begin{tabular}{ccccccccc}
\hline \multicolumn{9}{c}{$\mathbf{2 0 1 0}$} \\
\hline Plot & Mean & Median & Mode & STD & Mean & Median & Mode & STD \\
\hline 1 & 181.539 & 186 & 0 & 43.677 & 137.943 & 128 & 0 & 43.707 \\
2 & 164.555 & 160 & 153 & 17.843 & 115.845 & 114 & 115 & 12.567 \\
3 & 193.602 & 192 & 175 & 22.98 & 147.609 & 148 & 133 & 21.536 \\
4 & 185.979 & 189 & 0 & 40.432 & 142.759 & 142 & 128 & 36.225 \\
5 & 190.873 & 192 & 185 & 24.356 & 140.917 & 138 & 127 & 26.272 \\
6 & 189.138 & 191 & 152 & 31.912 & 144.69 & 143 & 111 & 27.622 \\
7 & 204.895 & 207 & 203 & 19.504 & 165.293 & 167 & 184 & 30.232 \\
8 & 204.669 & 209 & 221 & 19.83 & 180.882 & 195 & 213 & 36.578 \\
9 & 202.968 & 208 & 221 & 32.656 & 178.847 & 182 & 162 & 34.295 \\
10 & 209.864 & 211 & 203 & 16.081 & 189.876 & 191 & 182 & 22.157 \\
\hline
\end{tabular}




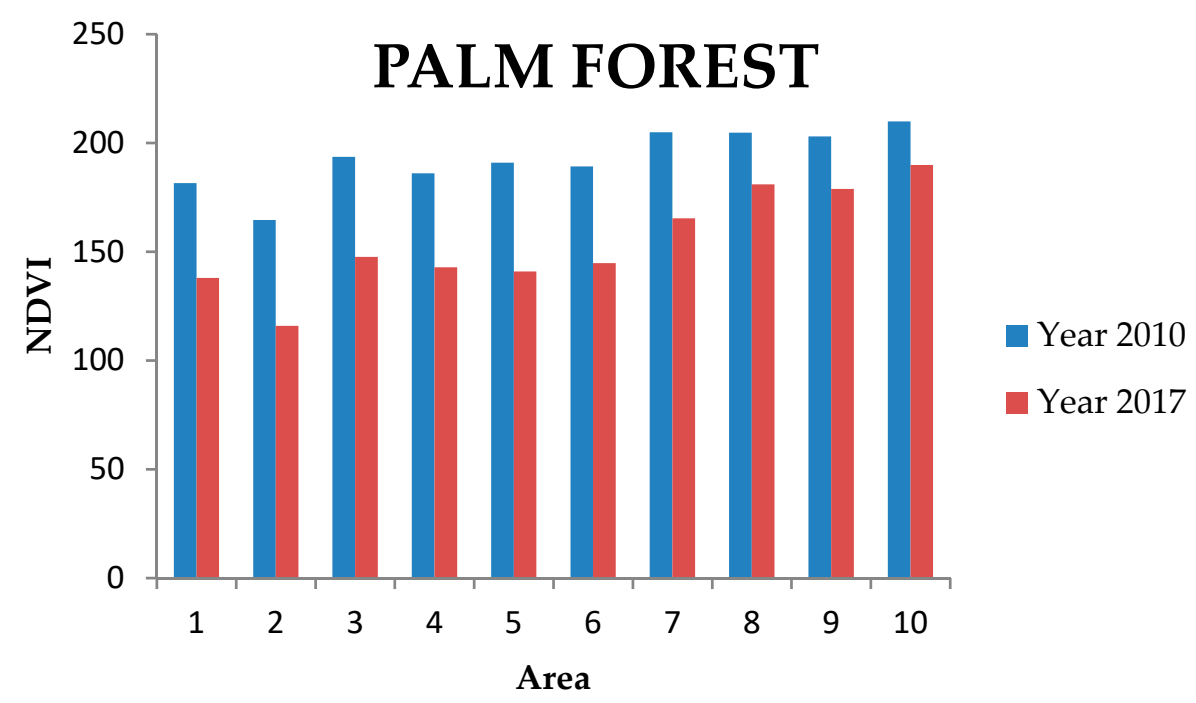

Figure 7. Comparison for mean NDVI between 2010 and 2017 in the palm forest area.

\subsection{Savannahs}

Of all the formations studied, the savannahs showed the least significant change. However, we can see that the NDVI decreased slightly between 2010 and 2017, as we can see in Table 7 and Figure 8.

Table 7. NDVI statistical results for the savannah area.

\begin{tabular}{ccccccccc}
\hline \multicolumn{9}{c}{2010} \\
\hline Plot & Mean & Median & Mode & STD & Mean & Median & Mode & STD \\
\hline 1 & 187.879 & 204 & 0 & 59.486 & 161.015 & 175 & 0 & 57.174 \\
2 & 203.811 & 202 & 231 & 20.035 & 177.277 & 181 & 194 & 25.472 \\
3 & 180.001 & 197 & 0 & 62.194 & 161.988 & 178 & 0 & 58.424 \\
4 & 201.589 & 202 & 197 & 21.731 & 185.887 & 190 & 210 & 24.736 \\
5 & 202.719 & 207 & 203 & 31.075 & 184.125 & 187 & 185 & 31.965 \\
\hline
\end{tabular}

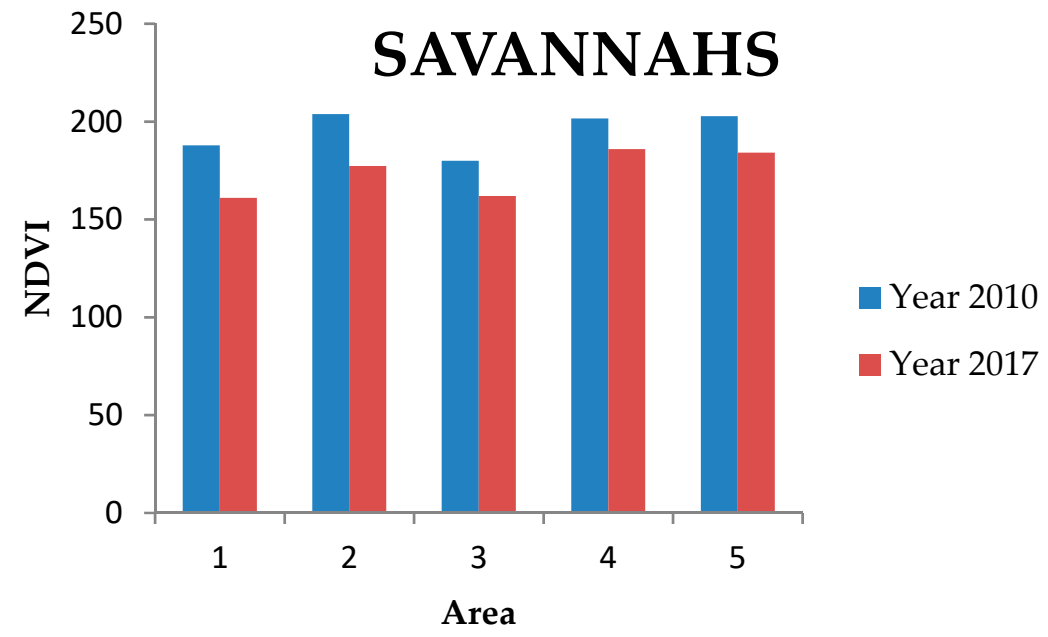

Figure 8. Comparison for mean NDVI between 2010 and 2017 in the savannah area.

\subsection{Other Areas}

The analysis of the areas called "Others" (occupied by villages and human settlements) leads to the conclusion that these areas of the park are the ones that have suffered the greatest degradation, as show the Table 8 and Figure 9. This degradation could be understood as related to the increase in population, which, as on the rest of the African Continent, is much higher in the vicinity of rivers 
and along the coast than in inland areas (e.g., almost $80 \%$ of Guinea-Bissau's population resides in the coastal zone). This fact has a very relevant impact upon the degradation of the mangrove swamps due to land reclamation by the increasing population, pointing precisely at this as the principal cause of the disappearance of mangals in the area.

Table 8. NDVI statistical results for other areas.

\begin{tabular}{ccccccccc}
\hline \multicolumn{9}{c}{$\mathbf{2 0 1 0}$} \\
\hline Plot & Mean & Med & Mod & STD & Mean & Med & Mod & STD \\
\hline 1 & 198.001 & 206 & 210 & 22.904 & 138.232 & 141 & 127 & 29.404 \\
2 & 174.002 & 168 & 160 & 23.094 & 120.754 & 116 & 127 & 24.455 \\
3 & 180.002 & 176 & 153 & 27.761 & 120.502 & 115 & 108 & 24.570 \\
4 & 192.330 & 199 & 210 & 21.652 & 138.950 & 141 & 127 & 23.948 \\
5 & 169.004 & 160 & 154 & 20.292 & 131.623 & 123 & 120 & 19.353 \\
6 & 171.549 & 169 & 170 & 17.043 & 133.269 & 130 & 127 & 20.556 \\
7 & 181.058 & 177 & 164 & 21.010 & 132.360 & 130 & 127 & 27.526 \\
8 & 168.093 & 161 & 154 & 19.932 & 115.000 & 112 & 107 & 14.581 \\
9 & 168.927 & 166 & 166 & 16.794 & 113.563 & 111 & 108 & 22.312 \\
10 & 169.124 & 162 & 150 & 19.498 & 111.125 & 111 & 115 & 13.799 \\
\hline
\end{tabular}

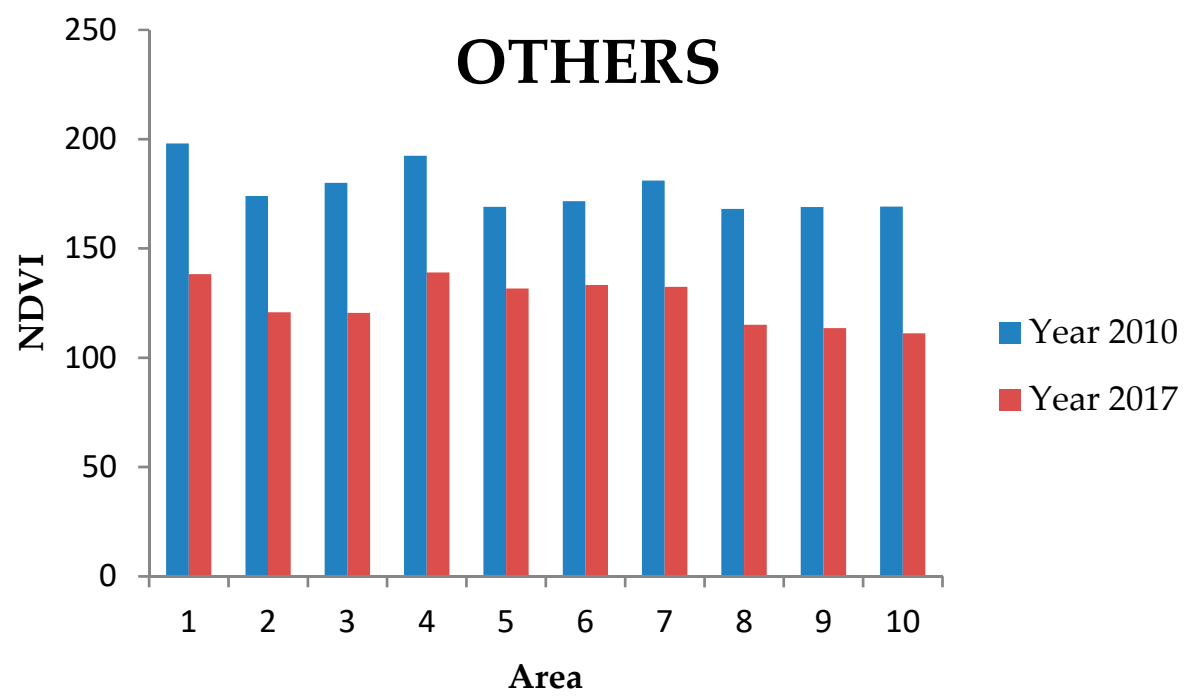

Figure 9. Comparison for mean NDVI between 2010 and 2017 in "other" area.

As a summary, Table 9 is presented with the mean NDVI for each of the classes studied.

Table 9. NDVI mean for each class.

\begin{tabular}{ccc}
\hline Class & $\mathbf{2 0 1 0}$ & $\mathbf{2 0 1 7}$ \\
\hline Manglar & 207.161 & 160.161 \\
Palm Forest & 192.808 & 154.466 \\
Paddies & 140.962 & 192.159 \\
Savannah & 195.200 & 174.058 \\
Others & 177.209 & 125.538 \\
\hline
\end{tabular}

As can be seen in the Figure 10, a decrease in the NDVI indices can be observed for all the vegetation types studied, except for the paddies. This means that, in general, the areas of the park covered with vegetation have been suffering an important loss, which implies a degradation of the natural park. 


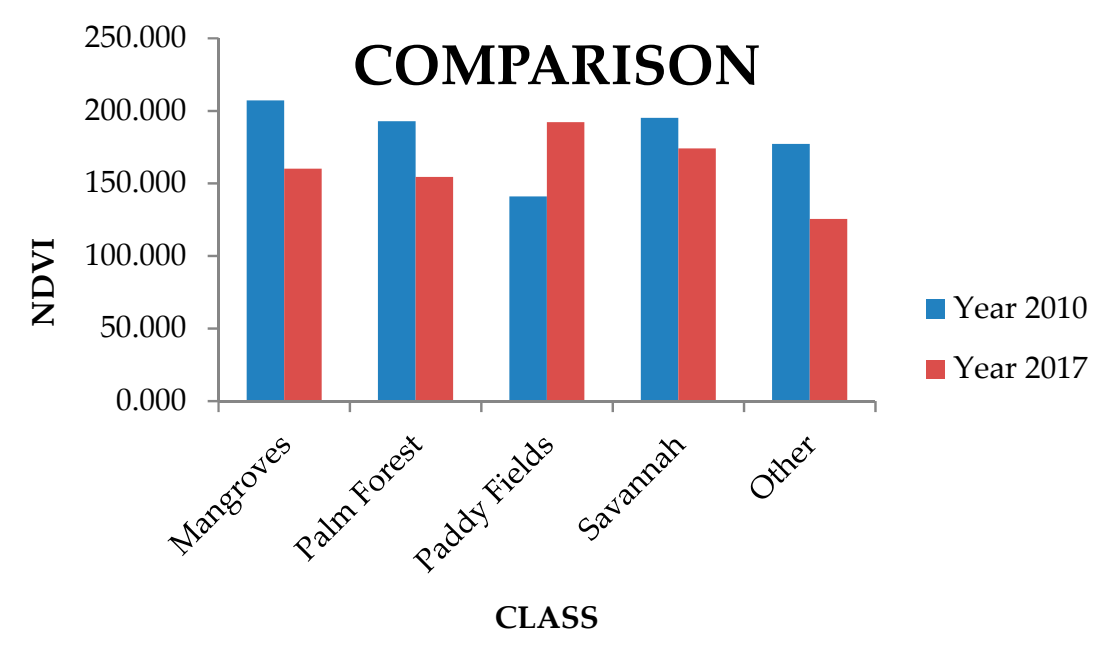

Figure 10. Comparison between average NDVI for the different classes.

\section{Discussion}

By using remote sensing techniques, such as vegetation indices calculated based on ASTER scenes and basemaps of Guinea-Bissau, it is demonstrated that the Cacheu River Mangroves Natural Park is undergoing changes in land use and vegetation. These changes were already detected in previous studies carried out by Vasconcellos et al. for the period of years 1956-1998 [4].

The observed changes in land use have effect on the degradation of the plant cover in one of the most important protected areas of Guinea-Bissau, containing one of the most significant mangrove formations in West Africa [26].

The analysis of the different areas studied between the years 2010 and 2017 indicates that the biggest changes occur in the mangrove swamps and in the areas closest to population settlements (areas classified as "other" in this study), for which there was a bigger decrease in the NDVI values over time. The gradual destruction of the mangals seems to be directly related to a change in land use, which could have shifted from mangrove forests to population centers, based on the interpretation of the results obtained and the literature review conducted.

To better understand the changes in land use, it is necessary to take into consideration some socio-economic issues in the area. The majority of the Guinean population directly depends upon the exploitation of biodiversity and natural resources for their survival [26]. The political instability of the country and the unemployment rate unfortunately contributes to an over exploitation of these natural resources. Agriculture and fishing are the two most important economic activities [4], and the cultivation of rice represents the main food crop. As pointed out by Vasconcellos et al. [4] in previous studies, one of the reasons for the degradation in these areas appears to be the systems of production of the rice. In the studied area, there are two main systems of rice production: i) Upland plateau or "Mpam-pam", or production by shifting cultivation; and, ii) cultivation in the hydromorphic mangrove soils. Itinerant rain rice cultivation or "shifting cultivation" is practiced mainly in forest ecosystems and savannahs [26]. The rice cultivation in the hydromorphic mangrove soils ("salty water fields") requires the deforestation of the mangals, and also involves the construction and maintenance of anti-salt dams [26]; as a consequence, not only is there a change in land use due to the shifting from manglars to rice crops, but also an additional degradation of the mangrove forests given the need of wood for the construction and maintenance of the dams. Another reason for the loss of mangroves, as pointed out by Lima da Faria et al. [5], is the consumption of fuel wood and charcoal, especially in human settlements.

The area of palm forest also experienced a decrease, although less prominent than the one observed for the mangrove swamps. The reason for the better maintenance of these areas is based on economic principles and is related to the production of fruits associated with these palms, which constitute an important agricultural product for export. The lesser change in NDVI in this area could also be due to 
the replacement of some native palm trees with cashews. Cashew cultivation began to spread after the independence of the country (from Portugal in 1974), motivated by the absence of credit for the reconstruction of dikes for the cultivation of rice in the mangrove area, and in more recent times, due to the demand in the international markets of cashew, as cashew does figure as the most important commercial crop for Guinea Bissau [34].

In the savannah area, the results obtained indicate a slight decrease, which could be associated with the cashew cultivation and the systems of rice production, known as "Mpam-pam". Both crops involve land clearing and cultivation till the land is no longer productive. Then, it is abandoned and left fallow [4]. Some of these lands, after enough time have elapsed, can recover their initial vegetation, but in other cases, it is not possible due to the degree of soil and nutrient depletion, which would need to be provided through fertilizers, amendments and other treatments, for which there are no financial resources, given the socio-economic situation of the country.

The villages, which in this study are covered as part of the area named as "Other", show the greatest degradation of all those studied. This is due to the increase in population which the country experienced during the years studied, which, as in the majority of African countries, is settled along river banks and the coast. These settlements have a particular impact on the degradation of the mangrove swamps and the appearance of more paddies, and that is the only area of study for which an increase in the NDVI values is observed. The increase of population density and the decrease in fertility of the land make that the proportion of land needed for food production is constantly increasing [4].

In summary, the underlying reason for the changes in land use, especially in mangrove areas, seems to be the increment of the human concentrations in these areas and the necessity to exploit their natural resources in order to meet the basic survival needs of the growing population [25]. Vasconcelos et al. [4] in their previous study, point to an increase in population mainly due to the arrival of refugees from southern Senegal (its northern neighbor). At the time of our study, the situation with regards to population growth in this area shall worsen most likely as a result of the period of political instability and the economic crisis experienced by the country.

Given all the changes in land use observed, it is understood that the park is not being managed in a sustainable way, despite the additional protection that is expected to be conferred by the declaration of the area as a Natural Park.

\section{Conclusions}

By studying the variations in the NDVI through the years 2010 to 2017, changes in land use in the Cacheu River Mangroves Natural Park in the Republic of Guinea-Bissau are observed. These changes, mainly affecting the mangrove swamps, are already identified in previous studies, and despite the declaration of the area as a Natural Park in 2000, it does not seem that any protective actions were put into place to aid in its conservation. Given the high ecological relevance of the mangals and the socio-economic importance of this vegetation type since the survival of the population settled depends mostly upon it, it is of utmost importance that multi-stakeholder attention, starting with the local government, is given to this area, and urgent action is taken to avoid its deforestation. The following measures are proposed to improve the sustainability of the park:

- Conducting education and awareness-raising campaigns to inform the local community of the importance of conserving these protected areas, especially the mangrove swamps, and promote their accountability regarding their conservation. Messages will need to emphasize, not only the global ecological relevance of the area, but also the importance of its sustainable management, since an uncontrolled exploitation will compromise their own survival.

- Drawing up a rational land use plan, respecting traditional uses and placing special emphasis on the mangrove swamps. This rational plan may consist of the following steps: 
As a first step, work on the reforestation of the most degraded mangrove swamps.

At the same time, conduct a reforestation of fallow areas with fast-growing species of autochthonous woody plants. This will allow obtaining wood for traditional uses and avoid further degradation of the mangals.

In the long-term, compile data from all species in the area to create an inventory or accurately update the existing one. This inventory will inform the design of an integral plan of the use of the natural resources and allow a rational exploitation, in order to preserve the sustainability of the area. Ideally, this integral plan would also account for:

- The implementation of a system for ongoing monitoring and control of the forest areas to ensure their optimum growth and maintenance, and;

- The conduct of regular management effectiveness evaluations.

Author Contributions: M.I.M.-L. and E.M.G.d.T. participated in all phases and contributed equally to this work. Funding: This research received no external funding.

Acknowledgments: This work was supported by ETS Ingeniería Civil de la Universidad Politécnica de Madrid.

Conflicts of Interest: The authors declare no conflict of interest.

\section{References}

1. Food and Agriculture Organization of the United Nations. Global Forest Resources Assessment 2015: Desk Reference; Food and Agriculture Organization of the United Nations: Roma, Italy, 2015. [CrossRef]

2. FAO. Global Forest Resource Assessment 2005. FAO For. Pap. 2005, 147, 129-147.

3. Malhi, Y.; Adu-bredu, S.; Asare, R.A.; Lewis, S.L.; Mayaux, P. African rainforests: Past, present and future. Philos. Trans. R. Soc. B Biol. Sci. 2013, 368, 20120312. [CrossRef] [PubMed]

4. Vasconcelos, M.J.P.; Biai, J.C.M. Land cover change in two protected areas of Guinea-Bissau (1956-1998). Appl. Geogr. 2002, 22, 139-156. [CrossRef]

5. De Faria, M.L.; Ferreira, P.M.; Melo, J.B.; Vasconcelos, M.J. A social assessment of forest degradation in the "Cacheu Mangroves Natural Park", Guinea-Bissau. Forests 2014, 5, 3327-3343. [CrossRef]

6. Ramsar. The Ramsar Sites Information Service 2015. Available online: https://rsis.ramsar.org/about (accessed on 10 August 2019).

7. Hogarth, P.J. Mangrove Ecosistems. In Encyclopedia of Biodiversity, 2nd ed.; Academic Press: Cambridge, MA, USA, 2013; pp. 10-22.

8. Adeel, Z.; Pomeroy, R. Assessment and management of mangrove ecosystems in developing countries. Trees 2002, 16, 235-238. [CrossRef]

9. Kathiresan, K.; Bingham, B.L. Biology of mangroves and mangrove Ecosystems. Adv. Mar. Biol. 2001, 40, 81-251. [CrossRef]

10. Lee, S.Y.; Primavera, J.H.; Dahdouh-Guebas, F.; Mckee, K.; Bosire, J.O.; Cannicci, S. Ecological role and services of tropical mangrove ecosystems: A reassessment. Glob. Ecol. Biogeogr. 2014, 23, 726-743. [CrossRef]

11. Badola, R.; Hussain, S.A. Valuing ecosystem functions: An empirical study on the storm protection function of Bhitarkanika mangrove ecosystem, India. Environ. Conserv. 2005, 32, 85-92. [CrossRef]

12. Kathiresan, K.; Rajendran, N. Coastal mangrove forests mitigated tsunami. Estuar. Coast. Shelf Sci. 2005, 65, 601-606. [CrossRef]

13. Tri, N.H.; Adger, W.N.; Kelly, P.M. Natural resource management in mitigating climate impacts: The example of mangrove restoration in Vietnam. Glob. Environ. Chang. 1998, 8, 49-61. [CrossRef]

14. Hussain, S.A.; Badola, R. Valuing mangrove ecosystem services: Linking nutrient retention function of mangrove forests to enhanced agroecosystem production. Wetl. Ecol. Manag. 2008, 16, 441-450. [CrossRef]

15. Rasolofo, M.V. Use of mangroves by traditional fishermen in Madagascar. Mangroves Salt Marshes 1997, 1, 243-253. [CrossRef]

16. Andreetta, A.; Huertas, A.D.; Lotti, M.; Cerise, S. Land use changes affecting soil organic carbon storage along a mangrove swamp rice chronosequence in the Cacheu and Oio regions (northern Guinea-Bissau). Agric. Ecosyst. Environ. 2016, 216, 314-321. [CrossRef] 
17. Vasconcelos, M.J.; Cabral, A.I.R.; Melo, J.B.; Pearson, T.R.; Pereira, H.D.A.; Cassamá, V.; Yudelman, Y. Can blue carbon contribute to clean development in West-Africa? The case of Guinea-Bissau. Mitig. Adapt. Strateg. Glob. Chang. 2014, 20,1361-1383. [CrossRef]

18. Saranraj, P.; Sujitha, D. Mangrove Medicinal Plants: A Review. Am.-Eurasian J. Toxicol. Sci. 2015, 7, $146-156$. [CrossRef]

19. Barbier, E.B. The protective service of mangrove ecosystems: A review of valuation methods. Mar. Pollut. Bull. 2016, 109, 676-681. [CrossRef]

20. Romañach, S.S.; DeAngelis, D.L.; Koh, H.L.; Li, Y.; Teh, S.Y.; Raja Barizan, R.S. Conservation and restoration of mangroves: Global status, perspectives, and prognosis. Ocean Coast. Manag. 2018, 154, 72-82. [CrossRef]

21. Catarino, L. Fitogeografia da Guiné-Bissau. In Provas de Doutoramento em Engenharia Agronomica; Universidade Técnica de Lisboa: Lisboa, Portugal, 2004.

22. Robertson, P. Data Zone Birds: Guinea-Bissau 2009. Available online: http://datazone.birdlife.org/userfiles/ file/IBAs/AfricaCntryPDFs/GuineaBissau.pdf (accessed on 5 August 2019).

23. Duarte, M.; Catarino, L.; Romeiras, M. Aspectos fitogeográficos das gramíneas na Guiné-Bissau. Port. Acta Biol. 2000, 19, 429-442.

24. Havik, P.J.; Monteiro, F.; Catarino, S.; Correia, A.M.; Catarino, L.; Romeiras, M.M. Agro-economic transitions in Guinea-Bissau (West Africa): Historical trends and current insights. Sustainability 2018, 10, 3408. [CrossRef]

25. Embalo, D.S.; Silva, A.S.; Biag, F. Plano de Gestão Parque Natural dos Tarrafes do Rio Cacheu-PNTC 2008-2018; Instituto da Biodiversidade e das Áreas Protegidas de Guiné Bissau: Bissau, Guinea Bissau, 2008; Available online: https:/rsis.ramsar.org/RISapp/files/45673327/documents/GW2229_mgt1505.pdf (accessed on 20 October 2019).

26. Government of Guinea-Bissau. Guinea-Bissau Fifth National Report to the Convention on Biological Diversity; Secretary of State for Environment and Tourism: Bissau, Guinea-Bissau, 2014.

27. Giri, C. Observation and monitoring of mangrove forests using remote sensing: Opportunities and challenges. Remote Sens. 2016, 8. [CrossRef]

28. Meneses-Tovar, C.L. El índice normalizado diferencial de la vegetación como indicador de la degradación del bosque. Unisylva FAO 2011, 62, 39-46.

29. Del, R.; Bernardo, L.; Período, E.N.E.L.; Carvacho, L.; Sánchez, M. Comparación de Índices de Vegetación a Partir de Imágenes Modis en la Región del Libertador Bernardo O’higgins, Chile, en el Período 2001-2005; Tecnologías de la Información Geográfica: la Información Geográfica al Servicio de los Ciudadanos; Secretariado de Publicaciones de la Universidad de Sevilla: Sevilla, Spain, 2010; pp. 728-737.

30. Sari, S.P.; Rosalina, D. Mapping and Monitoring of Mangrove Density Changes on tin Mining Area. Procedia Environ. Sci. 2016, 33, 436-442. [CrossRef]

31. Gupta, K.; Mukhopadhyay, A.; Giri, S.; Chanda, A.; Datta Majumdar, S.; Samanta, S. An index for discrimination of mangroves from non-mangroves using LANDSAT 8 OLI imagery. MethodsX 2018, 5 , 1129-1139. [CrossRef] [PubMed]

32. Satyanarayana, B.; Mohamad, K.A.; Idris, I.F.; Husain, M.L.; Dahdouh-Guebas, F. Assessment of mangrove vegetation based on remote sensing and ground-truth measurements at Tumpat, Kelantan Delta, East Coast of Peninsular Malaysia. Int. J. Remote Sens. 2011, 32, 1635-1650. [CrossRef]

33. Interior USD of the USGS Science for a Changing World n.d. Available online: https://glovis.usgs.gov (accessed on 13 May 2019).

34. Oom, D.; Catarino, L.; Temudo, M.P. Re-growth of mangrove forests of Guinea-Bissau. 2009. Available online: https://www.researchgate.net/profile/Duarte_Oom/publication/235677740_Re-growth_of_mangrove_ forests_of_Guinea-Bissau/links/0fcfd5127a7b3756b6000000.pdf (accessed on 7 November 2019).

(C) 2019 by the authors. Licensee MDPI, Basel, Switzerland. This article is an open access article distributed under the terms and conditions of the Creative Commons Attribution (CC BY) license (http://creativecommons.org/licenses/by/4.0/). 